\title{
KINERJA GURU PROFESIONAL (GURU PASCA SERTIFIKASI)
}

\author{
Badrun Kartowagiran \\ FT Universitas Negeri Yogyakarta (e-mail: badrunkw@yahoo.com; \\ HP: 08122781548)
}

\begin{abstract}
Professional Teachers' Post-Certification Performances. This study aims to investigate professional teachers' post-certification performances. It was an evaluation research study employing the goal-free evaluation model by Scriven. The sample, selected from a population of 548 teachers who have received professional incentives Sleman Regency, comprised 55 teachers (5 from kindergartens, 28 from elementary schools, 13 from junior high schools, 7 from senior high schools, and 7 from vocational schools), principals, and staff members of the Office of Education of Sleman Regency. The data were collected through questionnaires, interviews, focus group discussions, documents, and assessment sheets, and were analyzed using quantitative and qualitative descriptive techniques. The results show that the post-certification performances of the majority of professional teachers are not satisfactory yet, shown by the fact that of the 17 indicators, 7 indicators are good and 10 other indicators are fair.
\end{abstract}

Keywords: teacher performance

\section{PENDAHULUAN}

Guru memiliki peran strategis dalam bidang pendidikan, bahkan sumber daya pendidikan lain yang memadai sering kali kurang berarti apabila tidak didukung oleh guru yang berkualitas, dan begitu juga sebaliknya. Dengan kata lain, guru merupakan ujung tombak dalam upaya peningkatan kualitas layanan dan hasil pendidikan. Dalam berbagai kasus, kualitas sistem pendidikan secara keseluruhan berkaitan dengan kualitas guru (Beeby, 1969).

Namun, kenyataan menunjukkan bahwa kualitas guru di Indonesia masih tergolong relatif rendah. Hal ini antara lain disebabkan oleh tidak terpenuhinya kualifikasi pendidikan minimal, utamanya, bila mengacu pada amanat UU RI No. 14/2005 tentang Guru dan Dosen (UUGD), dan PP RI No. 19, 2005 tentang Standar Nasional Pendidikan (SNP). UUGD, dan PP RI. tersebut mengamanatkan kualifikasi pendidikan minimal D4 atau S1. Data dari Badan Penelitian dan Pengembangan Departemen Pendidikan Nasional (Balitbang Depdiknas) pada tahun 2005 menunjukkan terdapat 1.646 .05 (69,45\%) guru SD, SMP, SMA, SMK, dan SLB yang tidak memenuhi kualifikasi pendidikan minimal (Tim Sertifikasi Guru, 2006).

Pada Pasal 8 UUGD, dan Pasal 28 PP RI No. 19/2005, selain mempersyaratkan kualifikasi akademik bagi seorang guru, guru juga harus memiliki 
kompetensi sebagai agen pembelajaran pada jenjang pendidikan anak usia dini, dasar dan menengah. Kompetensi sebagai agen pembelajaran ini meliputi kompetensi pedagogik, kompetensi kepribadian, kompetensi profesional, dan kompetensi sosial.

Kompetensi kepribadian merupakan kemampuan personal yang mencerminkan kepribadian yang mantap, stabil, dewasa, arif, dan berwibawa, menjadi teladan bagi peserta didik, dan berakhlak mulia. Kompetensi pedagogik merupakan kemampuan yang berkenaan dengan pemahaman peserta didik dan pengelola pembelajaran yang mendidik dan dialogis. Secara substantif kompetensi ini mencakup kemampuan pemahaman terhadap peserta didik, perancangan dan pelaksanaan pembelajaran, evaluasi hasil belajar, dan pengembangan peserta didik untuk mengaktualisasikan berbagai potensi yang dimilikinya.

Kompetensi profesional merupakan kemampuan yang berkenaan dengan penguasaan materi pembelajaran bidang studi secara luas dan mendalam yang mencakup penguasaan substansi isi materi kurikulum matapelajaran di sekolah dan substansi keilmuan yang menaungi materi kurikulum tersebut, serta menambah wawasan keilmuan sebagai guru. Kompetensi sosial berkenaan dengan kemampuan pendidik sebagai bagian dari masyarakat untuk berkomunikasi dan bergaul secara efektif dengan peserta didik, sesama pendidik, tenaga kependidikan, orang tua/ wali peserta didik, dan masyarakat sekitar.
Menurut Keputusan Menteri Pendidikan Nasional No. 045 J /2002, kompetensi diartikan sebagai seperangkat tindakan cerdas dan penuh tanggung jawab yang dimiliki seseorang sebagai syarat untuk dianggap mampu oleh masyarakat dalam melaksanakan tugastugas sesuai dengan pekerjaan tertentu.

Dalam Permendiknas Nomor 18 Tahun 2007 tentang Sertifikasi Guru Dalam Jabatan tersirat bahwa empat kompetensi guru profesional ini dapat diukur melalui 10 komponen, yaitu: (1) kualifikasi akademik; (2) pendidikan dan pelatihan; (3) pengalaman mengajar; (4) perencanaan dan pelaksanaan pembelajaran; (5) penilaian dari atasan dan pengawas; (6) prestasi akademik; (7) karya pengembangan profesi; (8) keikutsertaan dalam forum ilmiah; (9) pengalaman organisasi di bidang kependidikan dan sosial; dan (10) penghargaan yang relevan dengan bidang pendidikan.

Sepuluh komponen portofolio merupakan refleksi dari empat kompetensi guru. Setiap komponen portofolio dapat memberikan gambaran satu atau lebih kompetensi guru peserta sertifikasi, dan secara akumulatif dari sebagian atau keseluruhan komponen portofolio merefleksikan keempat kompetensi guru yang bersangkutan.

Guru sebagai salah satu bagian dari pendidik profesional memiliki tugas utama mendidik, mengajar, membimbing, mengarahkan, melatih, menilai, dan mengevaluasi peserta didik pada pendidikan anak usia dini jalur pendidikan formal, pendidikan dasar, dan pendidikan menengah. Dalam melaksanakan tugasnya, guru menerapkan 
keahlian, kemahiran yang memenuhi standar mutu atau norma tertentu yang diperolehnya melalui pendidikan profesi.

Pengakuan kedudukan guru sebagai tenaga profesional dibuktikan dengan sertifikat pendidik dan diberikan kepada guru yang telah memenuhi syarat. Selanjutnya, bagi guru yang telah memiliki sertifikat pendidik berhak memperoleh penghasilan di atas kebutuhan hidup minimum dan jaminan kesejahteraan sosial. Penghasilan di atas kebutuhan hidup minimum meliputi gaji pokok, tunjangan yang melekat gaji, serta penghasilan lain berupa tunjangan profesi, tunjangan fungsional, tunjangan khusus, dan maslahat tambahan yang terkait dengan tugasnya sebagai guru yang ditetapkan dengan prinsip penghargaan atas dasar prestasi.

Menurut UUG Pasal 15, guru yang diangkat oleh satuan pendidikan yang diselenggarakan oleh Pemerintah atau pemerintah daerah diberi gaji sesuai dengan peraturan perundang-undangan. Guru yang diangkat oleh satuan pendidikan yang diselenggarakan oleh masyarakat diberi gaji berdasarkan perjanjian kerja atau kesepakatan kerja bersama. Guru yang diangkat oleh satuan pendidikan yang diselenggarakan oleh Pemerintah atau pemerintah daerah diberi gaji sesuai dengan peraturan perundang-undangan. Guru yang diangkat oleh satuan pendidikan yang diselenggarakan oleh masyarakat diberi gaji berdasarkan perjanjian kerja atau kesepakatan kerja bersama.

Uraian di atas memberikan gambaran bahwa sertifikasi guru berfungsi ganda, yakni sebagai sarana untuk meningkatkan kualitas pendidikan dan meningkatkan kesejahteraan guru. Namun yang menjadi masalah adalah apakah benar guru yang sudah lulus sertifikasi dan sudah mendapat tunjangan profesi itu kinerjanya juga tinggi? Untuk itu, perlu ada penelitian yang mampu mengungkap hal ini.

Diperlukan suatu penelitian yang bertujuan mengungkap kinerja guru yang sudah mendapat tunjangan profesi kaitannya dengan kemampuan: (1) menyusunan RPP dan melaksanakan pembelajaran; (2) kompetensi kepribadian dan kompetensi sosial; (3) membimbing siswa mengikuti lomba atau olimpiade; (4)) membuat modul dan media pembelajaran; (5) menulis artikel, melakukan penelitian, membuat karya seni/teknologi, menulis soalUNAS, menelaah buku, mengikuti kursus Bahasa Inggris, mengikuti diklat, mengikuti forum ilmiah; dan (6) aktivitas di organisasi.

\section{METODE}

Penelitian ini termasuk penelitian Evaluasi dan model yang dipilih adalah Goal-free Evaluation Model (Model Evaluasi Bebas Tujuan) oleh Scriven. Evaluasi model ini sangat tepat untuk mengungkap adanya perubahan perilaku yang terjadi sebagai dampak dari program yang diimplementasikan, melihat dampak sampingan baik yang diharapkan maupun yang tidak diharapkan dan membandingkan dengan sebelum program dilakukan.

Subjek penelitian ini adalah guru yang sudah mendapat tunjangan profesi yang ada di Kabupaten Sleman. 
Berdasarkan data dari Dinas Pendidikan Kabupaten Sleman dari semua jenjang TK, SD, SMP, SMA, dan SMK yang sudah mendapatkan tunjangan profesi ada sebanyak 548 guru, dengan rincian $\mathrm{TK}=50$ guru; $\mathrm{SD}=276$ guru; $\mathrm{SMP}=129$ guru; SMA $=74$ guru; dan SMK $=19$.

Untuk keperluan penelitian ini, tidak semua guru dijadikan subjek penelitian, namun diambil sampel beberapa guru yang dapat mewakili dari masingmasing jenjang pendidikan. Sampel yang diambil dari populasi tersebut ditentukan sebesar $10 \%$, yaitu sejumlah 55 guru, dengan rincian 5 guru TK, 28 guru SD, 13 guru SMP, 7 guru SMA, dan 2 guru SMK. Teknik pengambilan sampel secara proportional random sampling. Di samping itu, penelitian ini juga melibatkan kepala sekolah yang bertugas menilai kinerja guru pasca lulus terstifikasi, dan pihak Dinas Pendidikan Kabupaten Sleman sebagai narasumber.

Data penelitian ini dikumpulkan dengan menggunakan metode angket, wawancara, dan studi dokumen. Angket dan wawancara digunakan untuk mengungkap usaha guru dalam mempertahankan kinerja profesionalnya yang berupa angket langsung, serta angket berupa lembar penialian untuk menilai kinerja guru dalam melaksanakan pembelajaran dan kompetensi kepribadian dan sosial, merupakan angket tidak langsung karena yang mengisi kepala sekolah. Selanjutnya studi dokumen untuk mencermati RPP yang disusun oleh guru. Di samping itu, dilakukan Focus Group Discussion yang melibatkan guru, kepala sekolah, dan unsur dari Dinas Pendidikan untuk me- mantapkan dan melengkapi data atau informasi yang diperlukan.

Data yang terkumpul dianalisis menggunakan teknik deskriptif kuantitaif dan kualitatif. Teknik deskriptif kuantitatif digunakan untuk mendeskripsikan bagaimana usaha guru mengikuti pendidikan dan latihan (diklat), usaha guru mengikuti pelatihan, kualitas persiapan mengajar yang dibuat, usaha-usaha untuk meningkatkan prestasi akademik, usaha-usaha untuk mengembangkan profesi, usaha meningkatkan keikutsertaan dalam forum ilmiah, usaha-usaha untuk aktif dalam organisasi sosial dan atau pendidikan, dan kompetensi guru dalam pembelajaran, kepribadian, dan sosial.

\section{HASIL DAN PEMBAHASAN \\ Deskripsi Setting Penelitian}

Sasaran penelitian ini adalah para guru yang sudah lulus sertifikasi dan telah menerima tunjangan profesi pada tahun 2008 di lingkungan Dinas Pendidikan Kabupaten Sleman. Data tentang guru-guru tersebut, didasarkan pada data yang bersumber dari Tim Sertifikasi Guru Dinas Pendidikan Kabupaten Sleman, yaitu data pada bulan September, Oktober, dan November 2008. Jumlah keseluruhan guru yang telah lulus sertifikasi dan telah menerima tunjangan profesi sebanyak 548 orang dari semua jenjang pendidikan, sejak TK sampai dengan SMA SMK.

Untuk keperluan penjaringan data secara representatif, peneliti mengupayakan dengan mengambil sampel yang dapat mewakili kondisi lapangan dari semua jenjang pendidikan tersebut. Mengingat keberadaan guru-guru yang 
akan menjadi sampel secara geografis sangat variatif dilihat dari jarak-jangkauannya, maka sampel yang diambil sebesar $10 \%$ atau sebesar 55 guru dengan ketentuan setiap jenjang ada wakilnya secara proporsional. Dari sejumlah 55 guru yang menjadi sampel, akhirnya yang memberikan data secara valid lewat angket dan dokumen sebanyak 40 guru (TK=5; $\mathrm{SD}=16 ; \mathrm{SMP}=9$; $\mathrm{SMA}=8$; dan $\mathrm{SMK}=2$ ).

Para guru responden diundang dalam forum diskusi kelompok terbatas atau Focus Group Discussion (FGD) untuk memantapkan dan melengkapi data yang disampaikan lewat angket atau dokumen. Di samping itu, dalam FGD tersebut juga dihadirkan Kepala Sekolah dan unsur dari Dinas Pendidikan Kabupaten Sleman untuk memberikan penjelasan tentang kinerja guru pasca sertifikasi sesuai yang ketahuinya. Oleh karena itu, data yang diolah hanya yang berasal dari 40 guru dan sejumlah kepala sekolah yang menilai guru sampel yang menjadi bawahannya dikombinasikan dengan informasi dari hasil FGD.

\section{Kemampuan Guru Menyusun}

Rencana Pelaksanaan Pembelajaran

Sebagian besar guru (75\%) menyatakan bahwa semenjak lulus sertifikasi telah membuat Rencana Pelaksanaan Pembelajaran (RPP) sebanyak antara 1 sampai 12 kali karena hal tersebut merupakan kewajiban guru dan memang seharusnya RPP ditelaah atau diperbaiki setiap saat untuk menjaga kemutakhiran dan relevansinya. Sebaliknya, bagi guruyang belum menyusun RPP dengan mempertimbangkan bah- wa RPP yang ada (disusun sebelum sertifikasi) masih relevan sehingga masih dapat digunakan.

Selanjutnya, hasil percermatan peneliti terhadap dokumen RPP yang disusun oleh para guru, menunjukkan bahwa kualitas RPP termasuk dalam kategori sangat baik, berada dalam kelompok skor $75 \%$ ke atas. Hal ini menunjukkan bahwa keprofesionalan guru dilihat dari aspek penyusunan RPP setidak-tidaknya masih tetap dijaga dalam kategori RPP yang sangat baik.

\section{Kemampuan Guru Melaksanakan Pembelajaran}

Apek yang dinilai dalam pelaksanaan pembelajaran secara garis besar mecakup: prapembelajaran, kegiatan inti pembelajaran, dan penutup. Kegiatan inti pembelajaran meliputi sub-subaspek: penguasaan materi pelajaran, pendekatan/strategi pembelajaran, pemanfaatan sumber belajar/media pembelajaran, pembelajaran yang memicu dan memelihara keterlibatan siswa, penilaian proses dan hasil belajar, dan penguasaan bahasa. Tabel 1 menyajikan kemampuan guru pasca sertifikasi dalam melaksanakan pembelajaran.

Tabel 1 menunjukkan bahwa nilai kemampuan melaksanakan pembelajaran semua guru berada pada $25 \%$ kelompok atas (74 ke atas), bahkan ada yang mendapatkan nilai maksimal yaitu 2 orang sehingga dapat dikatakan bahwa pelaksanaan pembelajaran yang dilakukan oleh para guru sangat baik. 
Tabel 1. Nilai Kemampuan Guru

dalam Pelaksanaan Pembelajaran Pasca Lulus Sertifikasi

\begin{tabular}{ccc}
\hline $\begin{array}{c}\text { Nilai } \\
\text { Pelaksanaan } \\
\text { Pembelajaran }\end{array}$ & Frekuensi & Persentase \\
\hline 74 & 2 & $5 \%$ \\
75 & 2 & $5 \%$ \\
82 & 9 & $23 \%$ \\
83 & 2 & $5 \%$ \\
85 & 2 & $5 \%$ \\
86 & 5 & $13 \%$ \\
87 & 2 & $5 \%$ \\
89 & 2 & $5 \%$ \\
91 & 2 & $5 \%$ \\
92 & 2 & $5 \%$ \\
93 & 4 & $10 \%$ \\
94 & 2 & $5 \%$ \\
95 & 2 & $5 \%$ \\
96 & 2 & $5 \%$ \\
Jumlah & $\mathbf{4 0}$ & $\mathbf{1 0 0} \%$ \\
\hline
\end{tabular}

\section{Kompetensi Kepribadian dan Sosial}

Sebagaimana kondisi kompetensi pelaksanaan pembelajaran dan penyusunan RPP, kompetensi kepribadian dan sosial guru pasca sertifikasi juga menunjukkan gejala yang meningkat, setidak-tidaknya tetap, sama dengan sebelum lulus sertifikasi. Berdasarkan penilaian kepala sekolah, semua guru mendapat skor $80 \%$ atau termasuk kategori baik.

Kondisi secara umum kinerja guru berkenaan dengan kompetensi kepribadian dan sosial, juga disampaikan oleh sebagian besar kepala sekolah yang menjelaskan bahwa kinerja guru pasca lulus sertifikasi pada umum meningkat, para guru bekerja lebih baik. Hal tersebut ditunjukkan oleh peningkatan pada beberapa indikator kinerja guru, yang secara berturut-turut dari yang paling menonjol adalah: kedisiplinan meningkat, tanggung jawab meningkat, dan keteladanan meningkat. Selanjutnya diikuti oleh meningkatnya subkompetensi etos kerja, kerja sama, mau menerima kritik dan saran.

\section{Upaya Guru untuk Meningkatkan Kemampuan Akademik}

Guru yang sudah lulus sertifikasi secara berkelanjutan juga tetap meningkatkan prestasi akademiknya. Kegiatankegiatan yang dilakukan guru dapat dilihat pada Tabel 2.

Tabel 2 menunjukkan bahwa aktivitas atau upaya yang belum dilakukan oleh sebagian besar guru antara lain mengikuti lomba karya tulis ilmiah, menyiapkan karya tulis ilmiah untuk mengikuti lomba di masa yang akan datang, mengikuti kursus Bahasa Inggris, dan diminta Dinas Pendidikan Kabupaten untuk menjadi penatar/instruktur/tutor.

Namun demikian, ada kurang lebih $20 \%$ guru menyatakan usaha yang dilakukan untuk meningkatkan kemampuan akademik berupa menyiapkan karya tulis ilmiah untuk mengikuti lomba di masa yang akan datang dan/ atau menjadi penatar/instruktur/tutor atas permintaan Dinas Pendidikan Kabupaten. Di sisi lain, ada beberapa guru yang telah difasilitasi oleh sekolah untuk mengikuti kursus Bahasa Inggris di perguruan tinggi. Aktivitas lain yang 
dapat mendukung terpeliharanya atau untuk meningkatkan kemampuan akademik guru adalah membimbing mahasiswa PPL dan membimbing siswa untuk mengikuti lomba atau olimpiade.
Data yang ada menunjukkan bahwa lebih dari separuh guru telah melakukan pembimbingan terhadap siswa di sekolahnya yang mengikuti lomba maupun olimpiade mata pelajaran.

Tabel 2. Upaya Guru untuk Meningkatkan Kemampuan Akademik

\begin{tabular}{|c|c|c|c|c|c|c|c|}
\hline \multirow{2}{*}{ No. } & \multirow{2}{*}{ Usaha/Aktivitas Guru } & \multicolumn{6}{|c|}{ Persentase $(\mathrm{N}=40)$} \\
\hline & & Belum & $1 \mathrm{kali}$ & 2 kali & 3 kali & 4 kali & $\geq 5$ kali \\
\hline 1 & Mengikuti lomba karya tulis ilmiah & 92,5 & 7,5 & 0 & 0 & 0 & 0 \\
\hline 2 & $\begin{array}{l}\text { Menyiapkan karya tulis ilmiah untuk } \\
\text { mengikuti lomba di masa datang }\end{array}$ & 80 & 15 & 5 & 0 & 0 & 0 \\
\hline 3 & $\begin{array}{l}\text { Mengikuti kursus Bahasa Inggris } \\
\text { dengan biaya dari sekolah atau tidak } \\
\text { membayar sendiri }\end{array}$ & 87,5 & 12,2 & 0 & 0 & 0 & 0 \\
\hline 4 & $\begin{array}{l}\text { Mengikuti kursus Bahasa Inggris } \\
\text { dengan biaya sendiri }\end{array}$ & 92,5 & 7,5 & 0 & 0 & 0 & 0 \\
\hline 5 & $\begin{array}{l}\text { Diminta dinas pendidikan kabupaten } \\
\text { untuk menjadi penatar/instruktur/ } \\
\text { tutor }\end{array}$ & 80 & 12,5 & 5 & 2,5 & 0 & 0 \\
\hline 6 & Membimbing mahasiswa PPL & 50 & 32,5 & 12,5 & 5 & 0 & 0 \\
\hline 7 & $\begin{array}{l}\text { Membimbing siswa untuk mengikuti } \\
\text { lomba atau olimpiade }\end{array}$ & 45 & 23,5 & 20 & 7,5 & 0 & 5 \\
\hline
\end{tabular}

Upaya Guru untuk Mengembangkan Profesi

Aspek lain yang juga menjadi tolok ukur guru profesional adalah bagaimana guru tersebut berupaya mengembangkan profesinya sesuai dengan bidang studi atau kewenangan mengajar yang diembannya. Kondisi para guru pasca sertifikasi di Kabupaten Sleman berkenaan dengan kegiatan-kegiatan tersebut, disajikan pada Tabel 3 berikut ini.

Tabel 3 menunjukkan bahwa sebagian besar guru belum melakukan upaya atau aktivitas yang mendukung pengembangan profesinya. Aktivitas untuk mengembangkan profesi yang agak intensif dilakukan oleh guru adalah menulis buku/modul dan membuat media pembelajaran, namun masih sedikit yang menulis artikel untuk dimuat dalam jurnal, majalah, atau surat kabar. Lebih-lebih untuk aktivitas lain yang memerlukan keahlian atau kemampuan khusus antara lain menulis soal ujian nasional, mnelaah buku, dan mengerjakan karya teknologi/seni, baru sebagian kecil guru yang sudah menekuninya. 
Tabel 3. Upaya Guru untuk Mengembangkan Profesi

\begin{tabular}{clcccccc}
\hline \multirow{2}{*}{ No. Usaha/Aktivitas Guru } & \multicolumn{7}{c}{ Persentase (N=40) } \\
\cline { 3 - 8 } & Belum & $\mathbf{1}$ kali & 2 kali & $\mathbf{3}$ kali & $\mathbf{4}$ kali $\geq \mathbf{5}$ kali \\
\hline 1 & Menulis buku/modul & 65 & 12,5 & 10 & 2,5 & 2,5 & 7,5 \\
2 & Menulis artikel yang telah dimuat & 90 & 5 & 2,5 & 0 & 0 & 2,5 \\
& dalam jurnal, majalah, atau surat & & & & & & \\
& kabar & & & & & & \\
3 & Menulis soal ujian nasional (UN) & 90 & 7.5 & 2,5 & 0 & 0 & 0 \\
4 & Menjadi penelaah buku & 90 & 7,5 & 0 & 0 & 0 & 0 \\
5 & Membuat media pembelajaran & 57,5 & 20 & 10 & 10 & 2,5 & 0 \\
6 & Melakukan penelitian & 82,5 & 17,5 & 0 & 0 & 0 & 0 \\
7 & Menyiapkan proposal penelitian & 82,5 & 17,5 & 0 & 0 & 0 & 0 \\
8 & Telah menyelesaikan karya & 87,5 & 12,5 & 0 & 0 & 0 & 0 \\
& teknologi/seni & & & & & & \\
9 & Sedang mengerjakan karya & 97,5 & 2,5 & 0 & 0 & 0 & 0 \\
& teknologi/seni & & & & & & \\
\hline
\end{tabular}

Tabel 3 juga menunjukkan bahwa aktivitas-aktivitas yang tidak berkait langsung dengan proses pembelajaran belum disentuh oleh sebagian besar guru, yaitu menyiapkan proposal penelitian dan melakukan penelitian. Beberapa alasan mengapa beberapa kegiatan ada yang tidak dilakukan atau diupayakan dikarenakan guru belum diberi kesempatan, belum terbiasa menulis atau meneliti, atau kesibukan kegiatan lain di sekolah.

\section{Keikutsertaan Guru dalam Pendidikan dan Pelatihan}

Data menunjukkan bahwa lebih dari separuh guru $(52,5 \%)$ belum mengikuti diklat dengan biaya yang ditanggung oleh sekolah atau tidak membayar sendiri. Di antara guru yang pernah mengikuti diklat dengan biaya dari sekolah atau tidak membayar sendiri, paling banyak mengikuti diklat satu kali, sedang jumlah mengikuti diklat paling banyak empat kali.
Selain itu, guru-guru yang mengikuti diklat dengan biaya sendiri ada sebanyak 17,9\%, sedangkan sebagian besar menyatakan belum mengikuti diklat dengan biaya yang ditanggung sendiri. Beberapa hal yang menyebabkan para guru tidak mengikuti diklat antara lain belum ada kesempatan yang diberikan sekolah serta kurang relevansinya diklat yang ada dengan bidang studi yang diampunya. Meskipun demikian, dapat dikatakan bahwa sekitar $25 \%$ guru semenjak menerima tunjangan profesi sudah mengikuti diklat dua kali atau lebih baik dengan biaya sekolah maupun biaya sendiri.

Hal yang perlu dibanggakan adalah bahwa sebagian besar guru ternyata sudah berusaha untuk mencari informasi tentang diklat yang relevan untuk diikuti, bahkan di antara guru (10\%) ada yang mencari informasi tiga sampai lebih dari lima kali semenjak menikmati tunjangan profesi tersebut. Hal ini berarti bahwa para guru sebenarnya ber- 
upaya secara aktif untuk meningkatkan kemampuan dirinya lewat pendidikan dan latihan yang relevan.

\section{Keikutsertaan Guru dalam Forum Il-} miah

Sebagai tenaga profesional, guru juga dituntut aktif mengikuti forumforum ilmiah terutama yang relevan dengan tugas dan kewenangan serta tanggung jawabnya di sekolah. Usaha atau aktivitas guru dalam mengikuti forum ilmiah, disajikan pada Tabel 4 . Pada tabel ini ditunjukkan bahwa hampir $40 \%$ guru telah mengikuti forum ilmiah, di antara guru bahkan ada yang sampai lebih dari tiga kali mengikuti seminar meskipun dengan membayar sendiri. Jika dibandingkan antara yang mengikuti seminar didanai sekolah dan dibayar sendiri, sangat tipis perbedaannya, hanya $2,5 \%$, lebih banyak yang mengikuti seminar dengan dana sekolah atau tidak membayar sendiri. Jika dilihat upaya guru sebatas mencari informasi kegiatan forum ilmiah, dapat diketahui bahwa hampir separuh guru telah berupaya mencari informasi, bahkan $7,5 \%$ di antara guru sudah mencari informasi lima kali atau lebih.

Tabel 4. Keikutsertaan Guru dalam Forum Ilmiah

\begin{tabular}{|c|c|c|c|c|c|c|c|}
\hline \multirow{2}{*}{ No. } & \multirow{2}{*}{ Usaha/Aktivitas Guru } & \multicolumn{6}{|c|}{ Persentase $(\mathrm{N}=40)$} \\
\hline & & Belum & 1 kali & 2 kali & 3 kali & 4 kali & $\geq 5$ kali \\
\hline 1. & $\begin{array}{l}\text { Mengikuti seminar dengan biaya } \\
\text { ditanggung sekolah atau tidak } \\
\text { membayar sendiri }\end{array}$ & 60 & 25 & 7,5 & 2,5 & 2,5 & 2,5 \\
\hline 2. & $\begin{array}{l}\text { Mengikuti seminar dengan } \\
\text { membayar sendiri }\end{array}$ & 62,5 & 22,5 & 5 & 7,5 & 2,5 & 0 \\
\hline 3. & $\begin{array}{l}\text { Mencari informasi tentang } \\
\text { seminar yang relevan untuk } \\
\text { diikuti }\end{array}$ & 52,5 & 15,0 & 22,5 & 2,5 & 0 & 7,5 \\
\hline
\end{tabular}

Bagi guru yang belum mencari informasi maupun mengikuti seminar, sebagian besar menyampaikan alasan bahwa guru belum memiliki kesempatan, kesibukan pembelajaran, atau kesibukan pekerjaan lain di sekolah.

\section{Keterlibatan Guru Menjadi Pengurus Organisasi}

Dalam kerangka untuk menyeimbangkan antara kegiatan akademik dan sosial, guru yang profesional juga disarankan untuk ikut ambil bagian dalam berbagai organisasi, baik organisasi pendidikan maupun sosial. Tabel 5 menunjukkan keterlibatan guru dalam organisasi baik pendidikan maupun sosial. 
Tabel 5. Keterlibatan Guru Menjadi Pengurus Organisasi

\begin{tabular}{llrrrrrr}
\hline \multirow{2}{*}{ No. } & \multicolumn{1}{c}{ Usaha/Aktivitas Guru } & \multicolumn{5}{c}{ Persentase (N=40) } \\
\cline { 2 - 7 } & Belum & 1 kali & 2 kali & 3 kali & 4 kali & $\geq 5$ kali \\
\hline 1. & $\begin{array}{l}\text { Menjadi pengurus organisasi } \\
\text { pendidikan (misal: PGRI, ISPI) }\end{array}$ & 70 & 25 & 5 & 0 & 0 & 0 \\
2. & 77,5 & 20 & 0 & 2,5 & 0 & 0 \\
& $\begin{array}{l}\text { Berusaha menjadi pengurus } \\
\text { organisasi pendidikan }\end{array}$ & & & & & & \\
3. & $\begin{array}{l}\text { Menjadi pengurus organisasi sosial } \\
\text { 4. }\end{array}$ & 52,5 & 35 & 7,5 & 5 & 0 & 0 \\
& $\begin{array}{l}\text { Berusaha menjadi pengurus } \\
\text { organisasi sosial }\end{array}$ & 70 & 15 & 10 & 5 & 0 & 0 \\
\hline
\end{tabular}

Menjadi pengurus organisasi baik bidang pendidikan maupun sosial juga menjadi salah satu kriteria keprofesionalan seorang guru. Tabel 5 menunjukkan bahwa ada 30\% guru yang menjadi pengurus organisasi pendidikan, baik tingkat kecamatan, kabupaten, maupun provinsi, bahkan ada $47,5 \%$ guru mengaku menjadi pengurus organisasi sosial yang bervariasi dari tingkat desa sampai kabupaten. Sebagian besar di antara guru yang duduk menjadi pengurus organisasi telah menjadi pengurus satu kali periode, namun juga ada yang sudah tiga kali periode kepengurusan. Selain itu, ada sekitar $22,5 \%$ sampai $30 \%$ guru yang telah berusaha dapat duduk menjadi pengurus organisasi pendidikan atau sosial. Hal ini menujukkan bahwa guru berkeinginan untuk tetap menjaga keprofesionalannya sebagai guru.

\section{PENUTUP}

\section{Kesimpulan}

Berdasarkan sajian data dan pembahasan, maka hasil penlitian ini dapat didimpulkan bahwa kinerja sebagian besar guru profesional (pasca sertifikasi) yang ada di Kabupaten Sleman belum baik; dari 17 indikator yang diteliti, 7 indikator baik dan 10 indikator lainnya belum baik. Secara rinci, simpulan itu dapat dijabarkan sebagai berikut.

- Kemampuan guru profesional (guru pasca sertifikasi) dalam menyusun RPP dan melaksanakan pembelajaran sudah baik.

- Berdasarkan penilaian kepala sekolah, kompetensi kepribadian dan sosial para guru yang sudah lulus sertifikasi dan telah menerima tujangan profesi sangat baik.

- Upaya sebagian besar guru dalam membimbing siswa mengikuti lomba atau olimpiade sudah baik.

- Usaha sebagian besar guru yang telah lulus sertifikasi dan telah menerima tunjangan profesi dalam: (1) membuat modul; dan (2) membuat media pembelajaran baik.

- Upaya atau aktivitas sebagian besar guru yang telah lulus sertifikasi dan telah menerima tunjangan profesi masih belum menggembirakan, terutama yang terkait dengan (1) penulisan artikel; (2) penelitian; (3) membuat karya seni/teknologi; (4) menulis soal UNAS; (5) menelaah buku; (6) 
mengikuti kursus Bahasa Inggris, (7) mengikuti diklat, dan (8) mengikuti forum ilmiah, meskipun ada sebagian guru yang gigih mencari informasi diklat atau forum ilmiah yang mungkin diikuti.

- Aktivitas di organisasi pendidikan dan sosial belum baik, (1) ada sebagian $(47,5 \%)$ guru yang telah lulus sertifikasi dan telah menerima tunjangan profesi menjadi pengurus organisasi social; dan (2) 30\% guru menjadi pengurus organisasi pendidikan.

\section{Saran}

Setelah mencermati hasil dan kesimpulan penelitian ini, maka disarankan beberapa hal berikut.

- Meskipun telah lulus sertifikasi, para guru perlu mendapatkan bimbingan yang berkelanjutan, terutama yang terkait dengan kemampuannya menulis karya ilmiah dan melakukan penelitian. Perlu ada kerjasama antara dinas pendidikan Kabupaten Sleman dan perguruan tinggi untuk memfasilitasi diklat penulisan karya ilmiah dan penelitian pendidikan.

- Perlu ada suatu sistem yang mengharuskan guru untuk selalu tampil atau berkinerja tinggi, layak sebagai guru profesional. Selain melaksanakan pembelajaran dengan baik, guru profesional juga harus selalu berusaha meningkatkan kemmpuannya melalui melakukan penelitian, mengikuti pelatihan, atau kegiatan ilmiah lainnya.

\section{UCAPAN TERIMA KASIH}

Terima kasih saya ucapkan kepada Redaktur Jurnal Cakrawala Pendidikan yang telah memberi input untuk penyempuraan artikel ini. Terima kasih juga diucapkan kepada semua staf Jurnal Cakrawala Pendidikan.

\section{DAFTAR PUSTAKA}

Beeby, C.E. 1969. Qualitative Aspect of Educational Planning. Paris: Unesco.

Peraturan Menteri Pendidikan Nasional RI Nomor 045/ 2002. Kurikulum Inti Pendidikan Tinggi.

Peraturan Pemerintah RI Nomor 19 Tahun 2005. Standar Nasional Pendidikan.

Republik Indonesia. 2003. Undang $-U n-$ dang Republik Indonesia Nomor 20 Tahun 2003 tentang Sistem Pendidikan Nasional. Jakarta: Fokus Media

Republik Indonesia. 2005. Undang- Undang Republik Indonesia Nomor 14 Tahun 2005 Tentang Guru dan Dosen. Jakarta.

Tim. 2006. Naskah akademik. Jakarta: Ditjen Dikti.

Tim. 2008. Buku 3. Panduan penyusunan portofolio. Jakarta: Dikti. 